\title{
Coercion and the Prima Facie Duty to Obey the Law
}

\section{La coerción y el deber prima facie de obedecer la ley}

\author{
Jonathan CROwE* \\ Professor of Law \\ Bond University \\ https://orcid.org/0000-0002-2057-577 \\ jcrowe@bond.edu.au
}

RECIBIDO: 12/11/2019/ ACEPTADO: 25/02/2020

\begin{abstract}
This article examines the role of coercion in grounding a prima facie duty to obey the positive law. I argue that there is at least a weak prima facie duty to obey the positive law in a minimally effective and just legal system. The fact that a norm holds positive legal status within a minimally effective and just legal system gives people presumptive reason to believe that the norm is a salient and reasonable means of social coordination and therefore that they have pro tanto reason to follow it. Coercive sanctions may bolster the salience of social norms by giving people incentive to follow them. They also make it more likely that an agent's decision to follow a particular norm will be reasonable, by creating the prospect that the reasons supplied by the sanctions will override any deficits in the salience or reasonableness of the norm itself. A legal system with strong coercive enforcement is therefore more likely than a less coercive system (other things being equal) to present its subjects with both prima facie and pro tanto moral obligations. This reliance on coercion, however, carries a significant moral hazard, since it may bootstrap inefficient or unreasonable norms into a position of epistemological and moral weight.
\end{abstract}

Keywords: legal obligation, legal authority, prima facie duty, claims of law, coordination, coercion, punishment, sanctions.
Resumen: Este artículo examina el papel de la coerción en la fundamentación de un deber prima facie de obedecer la ley positiva. Sostengo que hay al menos un deber prima facie débil de obedecer la ley positiva en un sistema legal mínimamente efectivo y justo. El hecho de que una norma tenga un estatus legal positivo dentro de un sistema legal mínimamente efectivo y justo le da a las personas una razón presunta para creer que la norma es un medio fundamental y razonable de coordinación social y, por lo mismo, tienen una razón pro tanto para seguirla. Las sanciones coercitivas pueden reforzar la prominencia de las normas sociales al incentivar a las personas a seguirlas. También hacen que sea más probable que la decisión de un agente de seguir una norma particular sea razonable, al crear la posibilidad de que las razones proporcionadas por las sanciones anulen cualquier déficit en la notoriedad o razonabilidad de la propia norma. Por ello, un sistema legal con una sólida capacidad coercitiva tiene (en igualdad de condiciones) más probabilidades de presentar a sus ciudadanos tanto obligaciones morales prima facie, como obligaciones morales pro tanto. Sin embargo, esta dependencia de la coerción conlleva un riesgo moral significativo, ya que puede dotar a las normas ineficientes o irrazonables de peso epistemológico y moral.

Palabras clave: obligación legal, autoridad legal, deber prima facie, pretensiones legales, coordinación, coerción, castigo, sanciones.

\section{INTRODUCTION}

his article examines the role of coercion in grounding a prima facie
duty to obey the positive law. I argue that there is at least a weak prima
facie duty to obey the positive law in a minimally effective and just legal

* This article draws on arguments developed in Crowe, J., Natural Law and the Nature of Law, Cambridge University Press, 2019, ch 10. 
system. The notion of a prima facie duty is understood here in an epistemological sense. If $A$ has a prima facie duty to perform some action $\phi$, then $A$ has presumptive reason to believe that $A$ has decisive reason to $\phi$. I argue that the fact that an action is required by law in a system of the kind described above creates presumptive reason to believe that the action is rationally required. Law, on this view, does not possess generic moral force, but it does have epistemological salience as a guide to action.

The foundation for this view is supplied by the idea that each person has pro tanto reason to follow salient social norms where these represent reasonable modes of pursuing the common good of her community. I claim that the fact that a norm holds positive legal status within a minimally effective and just legal system gives people presumptive reason to believe that the norm is a salient and reasonable means of social coordination. It therefore generates a prima facie duty of the kind described above. The strength of this prima facie duty will depend upon the features of the law or legal system in question. The duty will tend to be more robust where the norms in question are backed by coercive sanctions.

Coercive sanctions may bolster the salience of social norms by giving people incentive to follow them. They also make it more likely that an agent's decision to follow a particular norm will be reasonable, by creating the prospect that the reasons supplied by the sanctions will override any deficits in the salience or reasonableness of the norm itself. These effects might obtain on the level of particular norms or on a system-wide basis. A legal system with strong coercive enforcement is more likely than a less coercive system (other things being equal) to present its subjects with both prima facie and pro tanto moral obligations to obey its edicts. This reliance on coercion, however, carries a significant moral hazard, since it may bootstrap inefficient or unreasonable norms into a position of epistemological and moral weight.

\section{The Claims of LaW}

Joseph Raz argues that 'it is an essential feature of law that it claims legitimate authority. ${ }^{1}$ This thesis raises two further questions. First, how is it possible that law presents claims? Second, what is the content of the claims in

1 RAZ, J, The Authority of Law, Clarendon Press, 1979, 30. 
question? The proposition that law presents claims to authority may at first appear puzzling. Law does not seem to be the right kind of thing to make claims. Critics of Raz's analysis, such as Ronald Dworkin, ${ }^{2}$ have accused him of anthropomorphism: humans may make claims, but law cannot. A plausible response to this challenge, however, is to emphasise the role of legal officials in imparting social significance to legal artifacts. ${ }^{3}$ Legal officials portray the law as authoritative; in this way, they make claims about law. The thesis that 'law claims authority' can be taken as shorthand for 'legal officials claim that law has authority'. There is nothing puzzling about that.

There may be another way of explaining how law presents claims. This alternative explanation would treat the enactment of a legal rule, not merely as a formal process leading to the production of a particular type of artifact, but also as a form of speech act. We might say that, in enacting a legal rule (or positing a legal norm), a legal official or body both (a) creates a legal artifact and (b) performs the speech act of making a legal claim. ${ }^{4}$ On this view, the claims of law are understood as claims made by legal officials in the act of legal enactment. We might usefully analyse the claim conveyed in legal enactment as including both a particular and a general component. The particular claim is that the specific rule expressed in the enactment confers an obligation. However, this claim, considered alone, invites a further question: by virtue of what authority does the claimed obligation arise? This question is pre-empted by the general claim: law has generic authority. ${ }^{5}$

The idea that the claims of law are made by legal officials on law's behalf goes some way towards vindicating Raz's proposal that law necessarily claims authority. However, it runs into difficulties in relation to forms of law that do not necessarily rely upon legal officials. ${ }^{6}$ A partial solution to this problem can be found in the idea that members of the community talk and think about law as having authority. The claims of law, then, might come partly from legal officials and partly from ordinary members of the community. People often

2 Dworkin, R, Fustice in Robes, Harvard University Press, 2006, ch 6-7; ID., 'Response', in S HeRSHOVITZ (ed.), Exploring Law's Empire: The Furisprudence of Ronald Dworkin, Oxford University Press, 2006, 306-7.

3 Compare Gardner, J, 'Law's Aim in Law's Empire', in S Hershovitz (ed.), Exploring Law's Empire..., op. cit., Oxford University Press, 2006, 213.

4 Compare ReInach, A, 'The A Priori Foundations of the Civil Law', trans John F Crosby, Aletheia 3, 1 (1983) 104-5.

5 Compare STEwarT, I, 'The Use of Law', Current Legal Issues 8 (2005) 259.

6 For discussion, see Crowe, Natural Law and the Nature of Law, ch 6. 
talk and think about law as if they have reason to do as the law requires, simply because it is the law; in doing so, they can be interpreted as making claims to generic authority on the law's behalf.

We have focused so far on what it means for law to claim authority. We can now turn to the content of this claim: what does it mean for law to claim authority? Raz offers a detailed and influential theory of authority: he calls it the service conception, because it attempts to explain how an authority assists or serves those to whom it applies. ${ }^{7}$ Raz argues that the function of an authority is to help people act on the reasons that bind them. It is meant to simplify the process of deciding how to act. People normally work out how they ought to behave by weighing up the reasons they have to act in different ways. For example, they may have reasons both for and against following a particular rule. A putative authority can only make a difference to people's decision-making processes if they do not have to weigh up whether to comply with it in each individual case. Otherwise, they will still have to consider all the relevant reasons and the authority will fail to serve its purpose.

Raz concludes that an authority only serves those whom it governs if it does more than provide reasons to act in a particular way. He therefore explains authority in terms of what he calls exclusionary reasons. ${ }^{8}$ An exclusionary reason is a reason to exclude or refrain from acting upon other relevant reasons. That is, it pre-emptively removes from the picture some of the reasons that people would otherwise have to consider in deciding how to act. An exclusionary reason 'is immune from the claim that it should be re-examined with a view to possible revision on every occasion to which it applies." A genuine authority, Raz contends, will simplify the reasoning process by providing both positive reasons for acting in a particular way and exclusionary reasons to disregard other competing reasons.

Raz, then, argues that law claims to provide exclusionary reasons. Law's claim to authority is not simply a claim that law supplies reasons. Rather, it is a claim that law pre-empts other normative factors. Law claims to dictate action within its sphere of application. It is assumed that people are not entitled to depart from the law unless it provides for its own exception: 'what is excluded by a rule of law is not all other reasons, but merely all those other reasons

\footnotetext{
RAZ, J, The Morality of Freedom, Oxford University Press, 1988, 56.

ID., Practical Reason and Norms, Oxford University Press, 1999, 35-48.

9 ID., The Autbority of Law, 33.
} 
which are themselves not legally recognised. ${ }^{10}$ Furthermore, law claims $l e-$ gitimate authority, as opposed to merely effective or de facto authority. ${ }^{11}$ Law does not claim that we should follow it based on force or threats alone. Rather, law claims that the authority it enjoys is well founded. It asserts a kind of moral authority over its subjects.

Other theorists have contested Raz's thesis that law claims legitimate authority. Mark Murphy, for example, argues that Raz gives us no reason to accept his thesis that law claims authority, as opposed to the weaker thesis that law is committed to the claim that it is backed by decisive reasons for action. ${ }^{12}$ Raz supports his view by reference to a range of characteristics of legal institutions, such as the way that judges and legislators formulate the demands of law. However, Murphy denies that Raz's description of these factors gives reason to adopt the Raz thesis over Murphy's weaker proposal. It is true that some of Raz's points in support of his thesis are equally consistent with Murphy's proposal. However, there are other points in support of Raz's position that Murphy does not mention. One relevant consideration is the way law is often presented as a self-contained normative system. This point, which is certainly noticed by Raz, ${ }^{13}$ comes to the forefront in the work of Hans Kelsen.

Kelsen depicts legal validity as deriving from a necessarily presupposed basic norm [Grundnorm]; the basic norm gives other norms in the legal order decisive force. Kelsen therefore maintains that law is a self-contained normative system, in the sense that it excludes the need to consult extra-legal principles in working out what one ought (legally) to do. ${ }^{14}$ Legal officials often seem to present the law as if this were true. Legal directives are typically presented not only as if they are backed by reasons for compliance, but also as if those reasons may be located without looking outside the law. The only reasons considered admissible in courtroom argument, for example, are those from within the law; if a norm has not been adopted as part of the law, it is generally treated as irrelevant. Courts typically only justify their rulings through legal arguments; they do not typically support their decisions with extra-legal reasons. Statutes likewise lay down rules of conduct and

10 Ibidem.

11 Ibid., 28-30.

12 Murphy, M C, Natural Law in furisprudence and Politics, Cambridge University Press, 2006, 52-6.

13 RAZ, Practical Reason and Norms, 170-7.

14 Compare Kelsen, H, General Theory of Law and State, trans Anders Wedberg, Russell and Russell, 1961, 373-6, 407-10. 
prescribe penalties in an authoritative tone without referring to extra-legal sources of obligation.

Raz's claim, then, seems plausible if one focuses on the way law is presented by legal officials. However, I am not sure whether the same applies to those forms of law where legal officials do not play a central role. I have argued elsewhere that law's function as an artifact is to serve as a deontic marker by creating a general sense of social obligation. ${ }^{15}$ This analysis is consistent with the idea that law claims authority, but it is also consistent with the weaker proposal that law claims to present decisive or weighty reasons for action. I doubt whether popular discourse around law is sufficiently clear or univocal to adjudicate between these proposals. It therefore seems to be going too far to say, as Raz does, that law necessarily claims authority. It does, however, seem to be a common and perhaps characteristic feature of law that it claims to function as a self-contained genre of discourse: that is, it claims to remove the need to look outside it when working out what one ought to do.

It is, of course, a different question whether law's claims to authority are well-founded. Raz argues they are not. He contends that while law claims to have legitimate authority, this claim is misleading. ${ }^{16}$ There may be good reasons to obey particular laws under many circumstances, but there is no generic obligation to obey the law as a whole. Raz observes that people have moral reasons to obey laws prohibiting murder, rape and so on. It is also common for people to have prudential reasons to obey the law, due to the risk of legal and social sanctions. However, he denies that everyone has good reason to obey the law all of the time. Indeed, he argues there is not even a prima facie obligation to obey the law. Many legal violations involve no moral wrongdoing and little or no risk of being caught and subjected to sanctions. In such cases, whether to obey is an open question. Raz, then, denies that we can meaningfully assess legal validity by reference to whether law actually possesses legitimate authority. The fact that law claims legitimate authority is sufficient to explain the central position it occupies in social life. People typically take it for granted that law has genuine authority, but this popular view rests on an

15 CROwE, Natural Law and the Nature of Law, ch 9.

16 RAZ, The Autbority of Law, ch 12. For other influential arguments along these lines, see SIMMONS, A J, Moral Principles and Political Obligations, Princeton University Press, 1979; GREEN, L, The Authority of the State (Oxford University Press, 1990); SмIтH, M B E, 'Is There a Prima Facie Obligation to Obey the Law?', Yale Law Fournal 82 (1973) 950. 
uncritical acceptance of law's claims. Raz therefore presents what we might describe as an error theory of law: ${ }^{17}$ law is generally taken to have authority, but this assumption is false.

\section{LAW AND COORDINATION}

John Finnis rejects Raz's view that law lacks genuine authority. ${ }^{18} \mathrm{He}$ contends that law possesses presumptive authority due to its role in facilitating social coordination. Finnis begins his argument from the observation that 'what is instrumental in securing a morally obligatory goal must itself be morally obligatory, unless there is some other instrumentality, equally or more serviceable. ${ }^{19}$ He goes on to argue that law is instrumental to the morally beneficial goal of social cooperation in service of the common good. Furthermore, law has advantages over other ways of achieving that goal. Law therefore has presumptive moral force. Finnis's coordination argument for legal authority has been strongly criticised for misapplying the concept of a coordination problem as used in game theory. ${ }^{20}$ Finnis's response is to deny that he ever intended to rely on the game theoretical concept of a coordination problem. ${ }^{21}$ Rather, he relies on a less technical argument that the law, taken as a whole, is a salient method of securing morally beneficial social cooperation.

Finnis's argument for legal authority fails. The central problem with the argument can be summarised as follows. Finnis seeks to establish that the law possesses generic authority as a specification of the duty to do one's share for the common good. It is true that some laws play a morally beneficial role in securing social coordination. However, others do not. Some laws are unnecessary for the common good: society would get on just as well without them. Other laws are harmful to social coordination: they may be well intentioned, but they are poorly planned, wasteful or unjust and therefore end up making

17 Compare Mackie, J L, Ethics: Inventing Right and Wrong, Penguin, 1977.

18 FINNIS, J, 'Law's Authority and Social Theory's Predicament', in Philosophy of Law: Collected Essays Volume IV, Oxford University Press, 2011.

19 Ibid., 48.

20 See, for example, GreEn, L, 'Law, Co-ordination and the Common Good', Oxford fournal of Legal Studies 3 (1983) 299.

21 FINNIs, 'Law's Authority and Social Theory's Predicament'; ID., 'Law as Coordination', in Philosophy of Law: Collected Essays Volume IV, Oxford University Press, 2011. 
things worse. Why, then, should we think that appeals to coordination yield a generic obligation to obey the positive law, rather than simply an obligation to obey any individual laws that actually succeed in advancing society's pursuit of the common good?

Finnis's response to this challenge seems to lie in his appeals to the special features of law that make the legal system, as a whole, a particularly salient mode of social coordination. He appeals to the idea that "law presents itself as a seamless web', ${ }^{22}$ in the sense that it forbids its subjects from picking and choosing between legal rules. However, just because law claims to be generically binding does not mean the claim is true. People have the option of picking and choosing among legal rules - and regularly do so - however much legal officials try to dissuade them. Furthermore, this type of selective legal obedience does not necessarily harm the common good. I noted above that some laws are socially harmful: they divert social efforts to pursue the common good away from more productive approaches. The common good would be better served in such cases if people ignored those laws in favour of other salient norms. Indeed, this is exactly what people often do.

Consider, for example, the following case:

Thomas Street: A local statute prescribes a speed limit on Thomas Street of 50 kilometres per hour $(\mathrm{km} / \mathrm{h})$. This speed limit is advertised by signs posted along the road. However, in practice, almost everyone drives on Thomas Street at a speed of $70 \mathrm{~km} / \mathrm{h}$.

What is the best approach for motorists to take when driving on Thomas Street? Should they stick to the advertised speed limit or keep up with the flow of traffic? Other things being equal, the most reasonable course of action may well be to drive at the faster speed, since it is generally safer to drive at the same speed as other road users. ${ }^{23}$ In other words, drivers on Thomas Street will fare better by disregarding the statutory speed limit in favour of the speed adopted by other drivers, than they would by regarding the traffic regulations as a seamless web. Situations of this kind are a common part of social life. Motorists confronted with a choice between the advertised speed limit and the speed dictated by social convention will often opt for the latter. This will

22 ID., 'Law's Authority and Social Theory's Predicament', 50; ID., 'Law as Coordination', 71.

23 I assume there are no other features of the road that make it clearly unsafe to drive at $70 \mathrm{~km} / \mathrm{h}$. 
frequently be the best choice for a motorist who wishes to do her share for the common good by promoting safety on the road.

The Thomas Street scenario involves a coordination problem. There is a range of possible (and safe) speeds that traffic on Thomas Street may travel; each person on the road is better off if the others travel at the same speed, but it does not matter (within the confines of safety) what speed it is. In other words, there is an aspect of the common good in this scenario that requires determination. As it happens, statute law prescribes a particular speed for travelling on Thomas Street; however, in the circumstances, that solution fails to be salient. The salient solution is to travel at $70 \mathrm{~km} / \mathrm{h}$, thereby breaking the law. A similar example is discussed by David Lewis in his classic study on convention. Lewis notes that the decision whether to drive on the right, or left-hand side of the road presents a coordination problem. Reasonable people will drive on the side that they expect other road-users to drive on. However, as Lewis explains, this type of case involves an additional complication:

If we do not drive on the right [in the United States], the highway patrol will catch us and we will be punished. So we have an independent incentive to drive on the right, and this second incentive is independent of how others drive. But it makes no important difference. If I expected the others to be on the left, I would be there too, highway patrol or no highway patrol. ${ }^{24}$

Lewis's point is clear. If the law prescribes a particular response to a coordination problem, but that response fails to gain salience among the relevant social group, the salient response trumps the law, provided that the payoff is high enough. (And, as Lewis notes, this may be the case even where the law is backed by sanctions.) The underlying lesson of these examples is that legal rules gain their moral force not from their legal status, per se, but from their status as a salient response to a social coordination problem. Many laws are, indeed, salient responses to coordination problems, but some laws go well beyond what is required for effective social coordination and others - such as the advertised speed limit on Thomas Street - do not track salient social norms. Finnis thinks there is good reason for people to respond to social coordination

24 Lewis, D, Convention: A Philosophical Study, Harvard University Press, 1969, 44 (emphasis added). 
problems by regarding the law as a seamless web. However, it is far from obvious that such an attitude is better suited to advance the common good than a more selective approach to legal obedience.

\section{COORDINATION WITHOUT AUTHORITY}

Finnis claims that the role of positive law in securing beneficial social coordination gives it generic authority over its subjects. I have already begun in the previous section to drive a wedge between these two ideas. I suggested above that insofar as there is an obligation to obey the law, this stems not from the legal status of the rule so much as its status as a salient response to a social coordination problem. It follows that where there is a clash between a legal rule and a salient social practice in a particular field of social coordination - as in the case of Thomas Street and Lewis's related example - the salient social practice will often win out. My suggestion is therefore that, although there may often be an obligation to obey the law due to its coordination function, it does not follow from this that law has generic authority.

I take it that this conclusion is similar to Raz's view. Finnis seeks to rebut Raz's position through reference to a hypothetical example. ${ }^{25} \mathrm{He}$ imagines that farmers on the banks of a river may not agree that there is sufficient reason for a national policy against river pollution. A voluntary anti-pollution campaign may not gain their support. However, Finnis contends that 'if and when a law is passed, things are changed for the farmer's practical reasoning.' The farmer may now reason that 'I should comply with this law, even though this law is neither in the national interest nor in my own. I should comply because I get many benefits from [...] the legal system in which I live. ${ }^{26}$ Finnis acknowledges that, on the face of it, this line of reasoning may apply just as well to a voluntary anti-pollution campaign as to a legal response. He argues that what sets the law apart from voluntary social conventions is 'the wide range of benefits' that it confers. ${ }^{27}$ These include social stability and equal enforcement. However, this argument sells voluntary social practices short.

25 FINNIS, 'Law's Authority and Social Theory's Predicament', 49-50.

26 Ibid., 49.

27 Ibid., 50. 
Finnis's argument that that social coordination requires 'unanimity or authority'28 arguably overlooks the possibility of non-state forms of legal ordering. Various forms of consensual and customary law play an important practical role in coordinating social action..$^{29}$ There is reason to think that these forms of non-state order will often outperform the dictates of a centralised authority as a response to the complex coordination problems faced by modern societies. Human knowledge about social organisation is subject to severe limitations. This is partly because humans have limited capacity to acquire, store and process complex information. More importantly, however, it is because of the complexity and dynamism of human society. The task of designing social institutions involves coordinating a diverse set of human actors, each with their own intricate sets of nested preferences. The process of identifying and aggregating these preferences is therefore deeply complex. Mechanisms such as the price system show that consensual agreements or evolved social practices can sometimes capture the information needed to coordinate preferences on a social level more effectively than any central planner. ${ }^{30}$

There is another point to be made here. One may well wonder whether Finnis's understanding of legal authority is conducive to core constitutional values such as the rule of law and fundamental rights. I have argued elsewhere that social action in service of the common good is best pursued within a political framework that contains a set of general, end-independent rules defining each person's protected sphere. ${ }^{31}$ These presumptive rules are then subject to positive duties to promote the interests of the poor and vulnerable. The precise form this balance takes will differ from community to community. It is likely that inefficient or unjust decisions will sometimes be made. Is it really desirable within this framework for citizens to adopt the farmer's attitude that 'I should comply with this law, even though this law is neither in the national interest nor in my own'? ${ }^{32}$ Those who think that responsible and active citizens have a duty to exercise independent judgment in relation to unjust or unnecessary laws have reason to be troubled by Finnis's stance on this issue.

28 FinNIS, Natural Law and Natural Rights, Oxford University Press, $2^{\text {nd }}$ ed, 2011, 232.

29 CROWE, Natural Law and the Nature of Law, ch 6.

30 See particularly HAYEK, F A, 'The Use of Knowledge in Society', American Economic Review 35

(1945) 519; ID., Law, Legislation and Liberty, University of Chicago Press, 1982, vol 1, ch 1-3.

31 Crowe, Natural Law and the Nature of Law, ch 5.

32 FINNIS, 'Law's Authority and Social Theory's Predicament', 49. 


\section{The Duty to Obey the LaW}

I have argued that law lacks genuine authority. Finnis's coordination argument fails to establish the moral force of law. What, then, is the closest we can get to vindicating the popular view that law possesses generic normative weight? I wish to conclude this chapter by arguing that we can make some sense of the notion of a generic duty to obey the law by utilising the concept of a prima facie duty. The idea of a prima facie duty, as I use it here, is an epistemological notion. If $A$ has a prima facie duty to perform some action $\phi$, then $A$ has presumptive reason to believe that $A$ has decisive reason to $\phi .{ }^{33} \mathrm{I}$ will suggest that there is a weak prima facie duty to obey the law in a minimally effective and just legal system. This means that the fact that an action is required by law creates weak presumptive reason to believe that the action is rationally required. Law, on this view, does not possess generic moral force, but it does have weak epistemological salience as a guide to action.

The foundation for this view is supplied by the idea that each person has reason to follow salient social norms where these represent reasonable determinations of the common good. The common good is a state of affairs in which each member of the community has a reasonable range of options for living a fulfilling life. Each person has robust pro tanto reason to pursue the common good, because it is good not only for her but also for everyone else in the community. ${ }^{34}$ This duty extends to following those social norms which give practical shape to the common good within a given community. Howeverr, this idea contains two important qualifications: first, the norms in question must be genuinely salient; and, second, they must be reasonable. The legal speed limit on Thomas Street fails to bind in reason because it fails the first of these conditions. The fact that a norm is recognised as part of the law in a given community therefore does not mean it will be genuinely salient as a determination of the common good. The legal status of a norm also provides no guarantee that it will be reasonable. Can we nonetheless say that the legal status of a norm holds epistemological weight in assessing whether it is rationally binding?

We saw earlier in this article that law often claims authority by presenting itself as a self-contained genre of discourse. This claim exerts pressure on

33 For further discussion, see CROWE, Natural Law and the Nature of Law, ch 5.

34 For a detailed argument to this effect, see ibid., ch 4. 
members of the community to accept the law as a unified system of norms. Suppose that law's claim to authority is generally given at least presumptive weight by the members of a particular community: that is, people generally think they have genuine reason to follow the law. A legal order with this kind of minimal effectiveness will give its norms a good chance of gaining salience within the community. This will be, at best, a rebuttable presumption, since scenarios like the Thomas Street case may evidently arise even in communities where law is generally obeyed. Nonetheless, the fact that a norm holds legal status within the community will give people presumptive reason to believe that the norm is a salient means of social coordination.

Does the fact that a norm is part of the law give presumptive reason to believe that it is not only salient, but reasonable? Suppose that the law in a given community passes a minimal standard of justice: it does not, for example, practice systematic discrimination against vulnerable groups. It is plausible that many of the legal norms of such a community will be reasonable specifications of the common good. The common good is open-ended: there are many different reasonable ways that it can be realised. Some laws will flatly contradict the demands of practical reason, but these rules are unlikely to be pervasive in a minimally just community. It is more likely that the norms of such a system will be unreasonable because they are arbitrary, inefficient or disproportionate compared to the alternative social solutions they displace. However, norms of this type may nonetheless be rationally binding. This is because the collective interest in maintaining a salient response to a coordination problem will often trump minor flaws in the relevant standards.

Suppose, for example, that the local government builds a set of traffic lights near your home in an inefficient location. The traffic lights have the effect of significantly slowing traffic without any commensurate gains in safety. There is a positive legal norm saying motorists must stop when the light turns red. This norm may well gain salience: if people are in the habit of obeying traffic signals in your community, they will probably stop at the red light most of the time. The norm is, however, unreasonable: it is an inefficient norm compared to the existing social practices at the relevant intersection. Imagine you are driving in your neighbourhood: the light turns red as you approach. What should you do? It seems that the most reasonable response in the circumstances is to stop at the red light. This is because the social interest in predictable traffic rules trumps the inefficiency of the norm.

Similar examples abound. Tax systems are often inefficient, arbitrary or distorted by special interests. Government inefficiency means many people 
pay more tax than is justified by the demands of the common good. Does this mean you should stop paying taxes? Not necessarily. It is likely that the government carries out many functions that are important for the common good. It may be true that these functions would be accomplished by other social institutions if the state was not involved, ${ }^{35}$ but once government enters the picture these institutions may be crowded out, leaving no feasible alternative. The importance of a salient social mode of providing important services may therefore trump even serious and widespread inefficiencies in the tax system. The likelihood of legal norms gaining salience therefore gives at least weak presumptive reason to believe it is reasonable to adopt them as a means of promoting the common good of the community.

I conclude that there is a weak prima facie duty to obey the law in a minimally well-functioning and just community. Legal duties are weak prima facie duties. This is much weaker than the common perception that law holds authority, in the sense of supplying exclusionary reasons to disregard extra-legal considerations, but it is the closest we get to vindicating that conception. Each person must nonetheless exercise judgment in working out whether to obey specific legal norms, since there is always the possibility that the law will be trumped by other salient solutions. There is also the possibility, even in a minimally just community, that particular legal norms will be so unreasonable that they ought not be followed. There may be a weak prima facie duty to follow the law, but this does not mean we should simply assume that following the law is the right thing to do. The extent to which the law commands our obedience must ultimately be assessed on a case by case basis.

\section{The Role of Coercion}

What role does coercion play in this picture? We have seen that there is a weak prima facie duty to obey the law in a minimally functional and just legal system. The robustness of this duty, however, may vary from norm to norm, as well as from system to system. The presence of coercive sanctions for disobeying the law will generally strengthen the duty. They accomplish this in two distinct ways. First, sanctions may bolster the salience of legal norms by giving people additional incentive to follow them. Second, sanctions (perhaps

35 See ibid., ch 6. 
counter-intuitively) may bolster the reasonableness of legal norms by making it more likely that their subjects will have genuine prudential or moral reasons to comply with them. These effects might apply to particular legal norms or on a wider systemic basis. They are relevant to practical reasoning at both epistemological and all-things-considered levels.

We saw above that the salience of a law or other social norm plays an important role in determining its moral force for members of the community. Social coordination is necessary to secure the common good. This, in turn, depends upon people knowing what they are required to do in order to cooperate with others in society. People will tend to adopt those social practices that present themselves as salient in planning their behaviour. It follows that the reasonable course of action for a person who wishes to contribute effectively to the common good is to seek to follow salient norms about who should contribute in which ways to the running of the community. Laws will often be salient, due to their special position of putative authority, but where they are not (as in the case of Thomas Street) it may be better to follow the salient norm than to comply with the law. Law can increase its likelihood of being salient by giving members of society incentives to follow it. These incentives might take various forms, but perhaps the most obvious one is coercive sanctions.

If a particular law is backed by weighty sanctions, it gives people reason to believe that it will be widely followed. It also, as a matter of fact, means that it is more likely to be widely followed, as people seek to avoid the sanction. The presence of sanctions therefore makes a legal norm more likely to be salient. This, in turn, makes it not only prudent but right for community members to adopt it as a guide to action. The important point to note in this context is that sanctions do not only make law more likely to be obeyed because they force people to do so, by effectively pitting prudential considerations against moral ones. Sanctions also give people additional moral reason to obey the law, because they make it more likely that the law is a salient mode of coordination for the common good. A law that is less just or efficient than competing social norms can still gain moral force if it is the salient option for coordinating social action. It accomplishes this, as noted previously, by crowding out superior solutions that might otherwise be generally adopted.

Sanctions, then, make legal norms more likely to be salient, potentially giving them moral force. They also make an agent's decision to follow a legal norm more likely to be reasonable. The presence of coercive sanctions for breaching a law gives the subject both self-regarding and other-regarding reasons to obey 
it. Most obviously, a person has reason to avoid the sanction insofar it is harmful for her personally. We might be disposed to regard this as a prudential reason, rather than a moral one. However, it is also a kind of moral reason, insofar as each person is properly for herself an object of moral consideration. Furthermore, a person will often have reason to avoid the sanction because it is harmful for others. It may harm her family (and perhaps her wider community), because it makes her less able to care for them and support them financially. It may harm her friends and loved ones, because it makes them worry about her well being. It may harm her work colleagues and clients, because she can no longer do her job. And it may harm society at large, because it imposes various kinds of costs on the community (for example, if she is jailed, the community may bear the cost of housing, clothing and feeding her). These reasons combine to make a compelling moral case for avoiding sanctions in many cases.

The initial impact of sanctions on practical reasoning about law will often be at an epistemological level. The initial knowledge people have about a particular law - or laws in their community - is likely to include the presence and general character of sanctions. This is likely to form part of the general store of social knowledge about the law. The presence of robust sanctions, for the reasons outlined above, supplies presumptive epistemological reason to believe that following the law is the right thing to do. This reinforces the relatively weak epistemological reason we have to believe that the law in general is morally binding. It is still true that law does not possess generic normative authority, so whether we should obey a specific law needs to be assessed on a case by case basis. However, a harsh and punitive legal system where any act of legal disobedience is likely to attract significant sanctions produces a relatively robust prima facie duty to follow the law, because there is a significant likelihood that the reasons associated with the sanctions will end up outweighing any countervailing moral considerations. This effect will be strongest in a legal system that is generally effective and just, as well as having robust sanctions. However, the same point may apply even to a significantly unjust and arbitrary legal system, provided that the sanctions are harsh enough to override these other factors. ${ }^{36}$

36 There are some laws that should never be followed, no matter how harsh the sanctions might be. However, even in a generally unjust and arbitrary system, many of the injustices that occur will likely not rise to this level of gravity. The level of injustice in the law will then have to be weighed against the reasons for compliance generated by the sanction. 
The availability of coercive sanctions, then, can bootstrap legal norms into a position of salience and reasonableness they would not otherwise hold, generating both epistemological and moral reasons for subjects to comply with them. It is tempting for legal authorities to make use of this mechanism in order to bolster the effectiveness of their rules. However, they should do so very cautiously. Legal sanctions carry a significant moral hazard, since they may bootstrap inefficient or unreasonable legal norms into a position of epistemological and moral force. Laws backed by weighty sanctions risk becoming salient, thereby crowding out social norms that might offer superior solutions to social coordination problems. They also risk becoming reasonable, putting subjects in a position where obeying an unjust or inefficient law is not only prudentially appealing, but also the morally correct thing to do. This would have the harmful consequence of incentivising widespread compliance with bad laws, but it would also impose the less obvious harm of making the subjects themselves complicit in any injustice that follows from their actions. ${ }^{37}$

\section{CONCLUSION}

Law plays an important role in coordinating social action in the name of the common good. However, this does not mean that law possesses generic authority. Rather, I have argued for the less ambitious claim that there is a weak prima facie duty to obey the positive law in a minimally effective and just legal system. Each person has weighty pro tanto reason to promote the common good; this, in turn, gives her pro tanto reason to follow social norms where they are salient and reasonable modes of pursuing this goal. Law is not guaranteed to be either salient or reasonable, meaning there is no generic obligation to obey the law because it is the law. Nonetheless, the fact that a norm holds positive legal status within a minimally effective and just legal system gives presumptive reason to believe that the norm is salient and reasonable. This gives rise to a weak prima facie duty to follow the law.

The presence of strong and consistent coercive sanctions makes a potentially important difference to the picture presented above. Sanctions make laws more likely to be salient, by increasing the likelihood that people

37 For discussion of the harms that moral agents suffer from being complicit in wrongdoing, see Crowe, Natural Law and the Nature of Law, ch 3. 
will follow them. They also make following the law more likely to be reasonable, by generating both prudential and moral reasons for compliance. The prima facie duty to obey the law is therefore more robust in relation to a law or legal system where sanctions play a prominent role. This might appear, superficially, to be a merit of such systems, but in fact it comes at a significant moral cost. Sanctions potentially mean that even unjust, arbitrary or inefficient laws can become morally binding. This not only decreases the scope for right-minded citizens to resist the laws (both in practice and as a matter of moral principle), but also makes them potentially complicit in wrongdoing.

This article has not sought to provide a general theory of when sanctions should (or should not) be used to encourage legal compliance. Rather, I have sought to highlight some factors that are relevant to this question, by discussing the relationship of sanctions to the prima facie duty to obey the law. I am disposed to think that legal sanctions should be used sparingly, because law can generally coordinate social action pretty well without them. ${ }^{38}$ However, my point in this article is a more modest one: whatever the proper role of sanctions might be, they should be deployed in a way that is attentive to their consequences for legal obligation and, more broadly, the social project of promoting the common good. This involves understanding, first, why sanctions are tempting for rulers - due not just to their practical utility, but also their moral impact on subjects - and, second, why this temptation needs to be balanced carefully against the moral hazards such measures pose.

\section{REFERENCE LIST}

Crowe, J, Natural Law and the Nature of Law, Cambridge University Press, 2019.

DwOrkin, R, Fustice in Robes, Harvard University Press, 2006.

- 'Response', in S. Hershovitz (ed.), Exploring Law's Empire: The Furisprudence of Ronald Dworkin (Oxford University Press, 2006).

FINNIS, J, 'Law's Authority and Social Theory's Predicament', in Philosophy of Law: Collected Essays Volume IV, Oxford University Press, 2011.

- 'Law as Coordination' in Philosophy of Law: Collected Essays Volume IV, Oxford University Press, 2011.

— Natural Law and Natural Rights, Oxford University Press, $2^{\text {nd }}$ ed, 2011.

38 Compare ibid., ch 6. 
GARDNER, J, 'Law's Aim in Law's Empire', in S. Hershovitz (ed.), Exploring Law's Empire: The Furisprudence of Ronald Dworkin, Oxford University Press, 2006.

Green, L, 'Law, Co-ordination and the Common Good', Oxford Fournal of Legal Studies 3 (1983) 299.

- The Authority of the State, Oxford University Press, 1990.

Hayek, F A, 'The Use of Knowledge in Society', American Economic Review 35 (1945) 519.

— Law, Legislation and Liberty, University of Chicago Press, 1982.

KeLsen, H, General Theory of Law and State, trans Anders Wedberg, Russell and Russell, 1961.

LEWIS, D, Convention: A Philosophical Study, Harvard University Press, 1969.

MaCKIE, J L, Ethics: Inventing Right and Wrong, Penguin, 1977.

Murphy, M C, Natural Law in Furisprudence and Politics, Cambridge University Press, 2006.

RAZ, J, The Authority of Law, Clarendon Press, 1979.

— The Morality of Freedom, Oxford University Press, 1988.

- Practical Reason and Norms, Oxford University Press, 1999.

ReInACH, A, 'The A Priori Foundations of the Civil Law', trans John F Crosby, Aletheia 3 (1983) 1.

Simmons, AJ, Moral Principles and Political Obligations, Princeton University Press, 1979.

Sмiтh, M B E, 'Is There a Prima Facie Obligation to Obey the Law?', Yale Law Journal $82(1973) 950$.

STEWART, I, 'The Use of Law', Current Legal Issues 8 (2005) 259. 
0000 